Zbigniew Pilat

Marek Pachuta

Ryszard Hylla

Jacek Kubica

\title{
Funkcjonalność i efektywność ekonomiczna zrobotyzowanego ukosowania blach
}

\section{Functionality and economic efficiency of the robotic plate bevel}

\section{Streszczenie}

Od połowy lat 90. XX w. PIAP wdrożył w zakładzie TAGOR S.A. w Tarnowskich Górach cztery zrobotyzowane stanowiska ukosowania blach. W pierwszym z nich zastosowano robota na torze jezdnym i cięcie tlenowe. W kolejnych wykorzystano roboty stacjonarne oraz cięcie tlenowe i plazmowe. Typ zastosowanego robota oraz organizacja gniazda determinują jego przydatność do obróbki detali o określonych gabarytach. Z kolei technologia cięcia wpływa na efektywność procesu. Wybór technologii wiąże się również z konkretnymi zagrożeniami bezpieczeństwa pracy, co ma także przełożenie na koszty. W artykule zostanie podjęta próba syntetycznej oceny różnych rozwiązań pod kątem ich zastosowania do określonego profilu produkcji. Wykorzystane zostaną doświadczenia zakładu.
Abstract

Since the mid-90s PIAP has implemented four robotic cells for metal sheets bevelling at the plant TAGOR SA in Tarnowskie Gory. The first one have used the robot on the track and oxygen cutting. In the next stationary robots as well as oxygene and plasma cutting were used. The type of the robot and the organization of cells determine the suitability of the whole installation for processing of workpieces of a particular size. Then the cutting technology affects the efficiency of the process. The choice of technology is also associated with specific safety hazards, which in effect influence the cost the production process. This article will attempt to synthetic evaluation of different solutions in terms of their application to a specific production profile. Experience of the plant will be used.

Key words: beveling, plate, robot

Słowa kluczowe: ukosowanie, blachy, robot

\section{Wstęp}

Ukosowanie krawędzi elementów przeznaczonych do spawania jest jedna $z$ podstawowych operacji technologicznych, stosowanych przy łączeniu blach, rur czy kształtowników o grubości ścianki przekraczającej $3 \mathrm{~mm}$. Zastosowanie do tej operacji, istotnej dla jakości złącza, zautomatyzowanego cięcia z użyciem robota przemysłowego, jest w Polsce stosunkowo nowym, innowacyjnym rozwiązaniem, pozwalającym na uzyskanie wielu korzyści zarówno wymiernych (znaczną poprawę jakości obróbki, zwiększenie wydajności, uzyskanie powtarzalności obróbki, możliwość obróbki wszystkich metali), jak i niewymiernych (poprawę warunków BHP, stosowanie przyjaznej środowisku technologii). W ogólnej ocenie konkretnego rozwiązania instalacji zrobotyzowanego ukosowania istotne znaczenie ma technologia cięcia, a także konfiguracja stanowiska i jego wyposażenie. Te cechy techniczne powinny zapewnić oczekiwaną funkcjonalność oraz optymalną efektywność ekonomiczną zrobotyzowanego stanowiska ukosowania, w odniesieniu do asortymentu produkowanych detali.

PIAP był prekursorem robotyzacji ukosowania w Polsce. W połowie lat 90. grupa aplikacyjna Instytutu współpracując ze specjalistami z TAGOR, wdrożyła w tym zakładzie pierwsze stanowisko $z$ robotem na torze jezdnym i cięcie tlenowe. W kolejnych latach opracowano gniazdo $z$ robotem stacjonarnym i cięciem tlenowym oraz robotem stacjonarnym i cięciem plazmowym. Doświadczenia z tych inwestycji oraz kilkuletniej eksploatacji różnych typów stanowisk pozwalają dokonać ich przekrojowej oceny i sformułować wskazówki dla wdrażających podobne rozwiązania w przyszłości.

mgr inż. Zbigniew Pilat, mgr inż. Marek Pachuta - Przemysłowy Instytut Automatyki i Pomiarów PIAP, Warszawa; mgr inż. Ryszard Hylla, mgr inż. Jacek Kubica - TAGOR S.A., Tarnowskie Góry.

Autor korespondencyjny/Corresponding author: mpachuta@piap.pl 


\section{Technologie procesu cięcia/ukosowania blach}

Cięcie i ukosowanie blach jest jedną z częściej wykonywanych operacji technologicznych w przemyśle budowy maszyn. Cięcie mechaniczne, ewentualnie wytłaczanie, stosuje się głównie do cienkich blach i w większości ma ono zastosowanie do cięcia prostych krawędzi. Do blach grubszych stosuje się obecnie różne technologie cięcia termicznego (gazowe, plazmowe, laserowe) lub wodnego. Każda $z$ tych technologii ma swoją specyfikę i zakres zastosowań, przy których jest najbardziej ekonomiczna. Aby dobrać najlepszą, należy rozważyć zarówno koszty przygotowania instalacji, cenę sprzętu do cięcia i urządzeń współpracujących, koszty eksploatacyjne, a przede wszystkim zakres ciętych materiałów, grubości detali, ich gabaryty i związaną z tym możliwość automatyzacji cięcia.

\section{Cięcie gazowe}

Polega na miejscowym spaleniu metalu (utlenianiu) w strumieniu czystego tlenu i odparowaniu powstałych tlenków. Proces rozpoczyna się od wstępnego podgrzewania do odpowiedniej temperatury (temperatury zapłonu). Do podgrzewania materiału może zostać zastosowany acetylen, propan lub gaz ziemny. Temperatura zapłonu wynosi dla żelaza $1050^{\circ} \mathrm{C}$, natomiast dla stali z domieszką $1,5 \%$ węgla - już $1380^{\circ} \mathrm{C}$. Ponieważ ze względu na to, że temperatura zapłonu materiału musi być niższa od jego temperatury topienia się, cięcie tlenowe może być zastosowane jedynie do stali konstrukcyjnych niskowęglowych i niskostopowych.

\section{Cięcie plazmowe}

Plazma, określana jako czwarty stan skupienia materii, jest zjonizowanym gazem, w którym atomy uległy rozpadowi na jony oraz elektrony. Cała objętość zajmowana przez plazmę jest elektrycznie obojętna. Jest ona bardzo dobrym przewodnikiem prądu, a jej opór elektryczny maleje ze wzrostem jej temperatury (odwrotnie niż w metalach).

Cięcie plazmowe polega na rozgrzaniu łukiem elektrycznym materiału do stanu płynnego i szybkim usunięciu go za pomocą silnego strumienia gazu, o prędkości zbliżonej do prędkości dźwięku. Plazma umożliwia precyzyjne przejście łuku elektrycznego w kierunku ciętego materiału i poddaje go działaniu zarówno termicznemu $\left(10000 \div 20000^{\circ} \mathrm{C}\right)$ jak i mechanicznemu (ciśnienie gazu). Cięcie plazmą jest procesem przeznaczonym do rozdzielania elektrycznie przewodzących materiałów. Powszechnie stosowanym gazem plazmotwórczym jest powietrze, w związku z czym nie istnieje ryzyko wybuchu.

\section{Cięcie laserowe}

Czynnikiem tnącym jest wiązka lasera i gaz techniczny pod ciśnieniem. Warunkiem uzyskania dobrej jakości cięcia i utrzymania tolerancji wymiarów ciętych elementów jest dokładne prowadzenie strumienia tnącego przez urządzenie do cięcia o dużej odporności na drgania i dobrej powtarzalności ruchów roboczych.

\section{Cięcie woda}

Cięcie następuje w wyniku skierowania wąskiego strumienia wody pod wysokim ciśnieniem, który skupia całą energię na niewielkiej powierzchni metalu ciętego, usuwając go. Energia kinetyczna strumienia jest przekształcana w pracę dekohezji materiału. Skrawany materiał nie podlega mechanicznym przeciążeniom i oddziaływaniom termicznym (temperatura cięcia to ok. $40^{\circ} \mathrm{C}$ ), a uzyskany półfabrykat nie wymaga dalszej obróbki. Urządzenia do cięcia wodnego to przeważnie specjalizowane maszyny.

Podstawowe cechy technologii cięcia wodą przygotowane na podstawie opracowań przeglądowych [1] i danych katalogowych urządzeń dostępnych na rynku

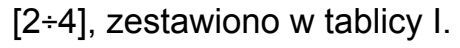

Tablica I. Porównanie technologii cięcia materiału

Table I. Metal cutting technologies assessment

\begin{tabular}{|l|c|c|c|c|}
\hline \multicolumn{1}{|c|}{ Cecha } & Cięcie gazowe & Cięcie plazmowe & Cięcie laserowe & Cięcie wodą \\
\hline Spektrum ciętych materiałów & ograniczone & szerokie & szerokie & wszystkie \\
\hline Grubość ciętych materiałów, mm & $3 \div 300$ & $0,5 \div 150$ & $0,5 \div 30$ & $0,5 \div 500$ \\
\hline Prędkość cięcia & niska & wysoka do $30 \mathrm{~mm}$ & wysoka do $6 \mathrm{~mm}$ & niska \\
\hline Czas przebijania & długi & b. krótki & b. krótki & b. krótki \\
\hline Występowanie strefy wpływu ciepła & szeroka & mała & minimalna & brak \\
\hline Powstawanie zgorzeliny & tak & minimalnie & brak & brak (eko) \\
\hline Szerokość szczeliny cięcia & szeroka & mała & najmniejsza & mała \\
\hline Równoległość szczeliny cięcia & b. dobra & średnia i dobra & b. dobra & b. dobra \\
\hline Jakość ciętych powierzchni & średnia & dobra & b. dobra & b. dobra \\
\hline Hałas & średni & duży & mały & mały \\
\hline Promieniowanie i dymy & średnie & duże & średnie & b. małe \\
\hline Światło & średnie & mocne & mocne, szkodliwe & brak \\
\hline Koszty inwestycyjne & małe & średnie & wysokie & wysokie \\
\hline Koszty serwisowe & małe & średnie & wysokie & wysokie \\
\hline Możliwość robotyzacji & duża & duża & średnia & mała \\
\hline
\end{tabular}


Jak widać z tego zestawienia różnych technologii cięcia metalu stosowanych w przemyśle, do automatyzacji ukosowania blach grubych z zastosowaniem robotów przemysłowych nadają się jedynie dwie pierwsze technologie: cięcie gazowe i cięcie plazmowe.

\section{Sposoby automatyzacji ukosowania blach}

\section{Ręczne i półautomatyczne}

Stosuje się, gdy narzędzie tnące (palnik) jest prowadzone przez operatora. Uzyskana w ten sposób powierzchnia po cięciu jest nierówna, często występują na niej wżery i „ząbki”. Wyrównanie powierzchni wymaga uciążliwego i pracochłonnego szlifowania. Dodatkowo w stanowiskach ukosowania ręcznego panują bardzo trudne warunki pracy. Operator znajduje się bezpośrednio przy płomieniu. Narażony jest na wdychanie niebezpiecznych dymów i oparów, na hałas, na poparzenia odpryskami i rozgrzanym detalem. Taki sposób ukosowania stosuje się z reguły w sytuacjach przymusowych, na przykład na montażu.

Poprawę jakości ukosowania można uzyskać (szczególnie krawędzi prostoliniowych) przez:

- wykorzystanie listew prowadzących palnik,

- instalowanie palnika na wózku z napędem elektrycznym.

Jeżeli narzędzie tnące (palnik) umieszczone jest na wózku z własnym napędem, a więc jego ruch odbywa się w sposób automatyczny, a bazowanie, odmierzanie fazy, sterowanie wózkiem i narzędziem w sposób ręczny, to mamy do czynienia z ukosowaniem półautomatycznym. Urządzenia, które służą do fazowania w ten sposób, noszą nazwę przecinarek półautomatycznych lub sekatorów (rys. 1). Jakość powierzchni uzyskana tym sposobem jest znacznie lepsza niż po ukosowaniu ręcznym.

Realizacja procesu ukosowania półautomatycznego jest wciąż bardzo pracochłonna, a jego efekt z punktu widzenia jakości często nie jest zadowalający. Szczególne problemy mają operatorzy przy wykonywaniu faz na łukach, zwłaszcza w miejscach przejścia z fazy prostoliniowej na odcinek łuku. Parametry geometryczne

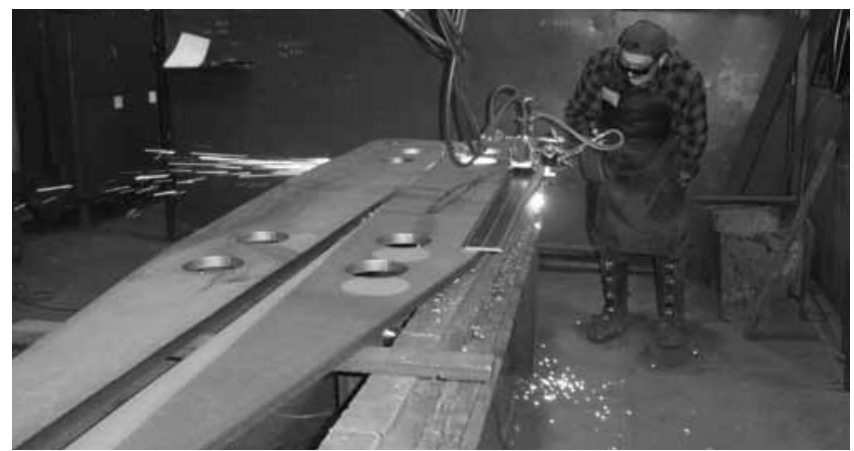

Rys. 1. Stanowisko ukosowania półautomatycznego z użyciem listwy prowadzącej palnik (sekatora)

Fig. 1. Workstation of semi-automatic bevelling with use of straight line cutting machine fazy są tam na ogół zaburzone, nierzadko pojawiają się wżery. To powoduje, że detal fazowany tą metodą musi być w kolejnej operacji doczyszczany i wyrównywany. Wydłuża to czas procesu ukosowania. Na obniżenie jego efektywności wpływa również to, że operator podczas fazowania jednego detalu musi go na ogół przekładać, zmieniając sposób mocowania, aby uzyskać dobry dostęp do kolejnych krawędzi. Dodatkowo w stanowiskach ukosowania półautomatycznego panują bardzo trudne warunki pracy, podobnie jak przy ukosowaniu ręcznym.

\section{Przy użyciu specjalizowanych automatów}

Przy produkcji detali w ilości od średnioseryjnej, opłaca się stosować specjalizowane automaty wyposażone w urządzenia do cięcia (palniki gazowe, plazmowe lub do cięcia laserem). Są to urządzenia typu CNC, często z możliwością automatycznego programowania kształtów wycinanych konturów i odcinków fazowanych na podstawie projektów CAD/CAM.

Producenci urządzeń do cięcia oferują całe spektrum różnych narzędzi, urządzeń i specjalistycznych stanowisk do fazowania. Jednymi z pierwszych były głowice trójpalnikowe do ukosowania, które pojawiły się ok. 40 lat temu. Początkowo kąt nachylenia palnika (a więc i kąt fazy) był ustawiany ręcznie, na stałe dla danego zadania. Później wprowadzono sterowane napędy elektryczne, które umożliwiły zmianę kąta w trakcie fazowania. Głowice te są w dalszym ciągu rozwijane. Służą one do jednoczesnego wycinania i ukosowania elementów, lub tylko do ukosowania i mogą być instalowane na wypalarkach lub indywidualnie na osobnych portalach. W pierwszym przypadku ich sterowanie jest integrowane ze sterowaniem wypalarek.

W ostatnim czasie pojawiły się na rynku głowice do ukosowania 3D wyposażone w palniki plazmowe. Sterowane są automatycznie za pomocą sterownika CNC. Głowice mają 2 lub 3 stopnie swobody, a mocowane na portalach o kolejnych 2 lub 3 stopniach, umożliwiają wówczas precyzyjne fazowanie blach, rur i profili podczas jednej operacji cięcia. Przykładową głowicę 3D przedstawiono na rysunku 2. a)

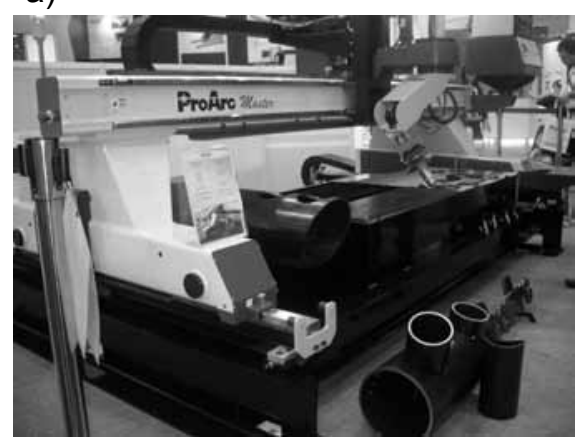

b)

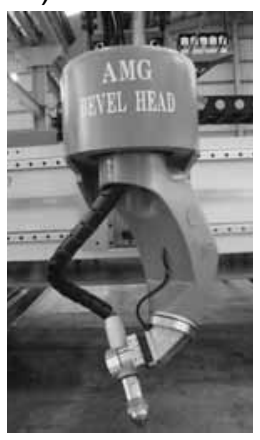

Rys. 2. Urządzenie CNC ProArc Master do cięcia i ukosowania blach na targach Schweissen\&Schneiden 2013 (United Proarc Corporation) (a), głowica do ukosowania 3D firmy Asia Machine Group (b) Fig. 2. CNC ProArc Master machine for cutting and bevelling of metal sheets, presented by United Proarc Corporation on Schweissen\&Schneiden 2013 fairs (a), the head for 3D bevelling from Asia Machine Group (b) 


\section{Przy użyciu robotów przemysłowych (aplikacja PIAP w TAGOR) [5, 6]}

Przy produkcji jednostkowej i małoseryjnej detali z blach grubych stosuje się zwykle zrobotyzowane stanowiska ukosowania. Robotyzacja procesów spawalniczych dotyczy dzisiaj ponad $25 \%$ wszystkich robotów zainstalowanych $w$ przemyśle [7]. Większość z nich wykorzystywano do spawania łukowego i zgrzewania punktowego. Do coraz częściej robotyzowanych technologii należą też procesy cięcia metalu, szczególnie wycinanie detali o małych gabarytach, docinanie otworów i fazowanie (ukosowanie) krawędzi elementów przeznaczonych do spawania. Robotyzacja tej ostatniej operacji jest tematem wspólnych prac badawczych i wdrożeniowych prowadzonych przez PIAP i TAGOR S.A. od kilkunastu lat. Generalnie, celem tych prac było zautomatyzowanie ukosowania detali wykonanych z blach o dużych grubościach (od $20 \mathrm{~mm}$ ) i średnich gabarytach, przy produkcji niskoseryjnej i dużym asortymencie detali. Do tej pory udało się zrealizować cztery stanowiska zrobotyzowane:

\section{Stanowisko $z$ robotem URP-6 na torze jezdnym}

Pierwsze zrobotyzowane stanowisko ukosowania blach w TAGOR S.A. zrealizowano ponad dwadzieścia lat temu (rys. 3). Zastosowano w nim opracowany w PIAP robot URP-6 na torze jezdnym (1). Detale do cięcia układane były na dwóch stołach (4) i (5), ustawionych wzdłuż toru, co umożliwiało obróbkę elementów długich i smukłych. W stanowisku wykorzystano cięcie tlenowe. Ciężkie detale dostarczane były na stoły za pomocą żurawików (10) z magazynów wejściowych (8) i po ukosowaniu przenoszone do pól odkładczych (9). W ramach realizacji wdrożenia opracowano i zastosowano m.in. automatyczną zapalarkę (7) i software'ową aplikację, która po awaryjnym przerwaniu wykonywania fazy pozwala na powrót do miejsca przerwania i kontynuowanie operacji fazowania $z$ tego punktu. Stanowisko sterowane było nadrzędnym sterownikiem PLC (3), wyposażonym w pulpit operatora. Szafa sterownicza robota (2) umieszczona była poza ogrodzeniem. Stanowisko to eksploatowane było ponad 12 lat. Zdemontowane zostało w 2009 r. ze względu na zużycie się części mechanicznych i wystąpienie dużej awaryjności po latach pracy.

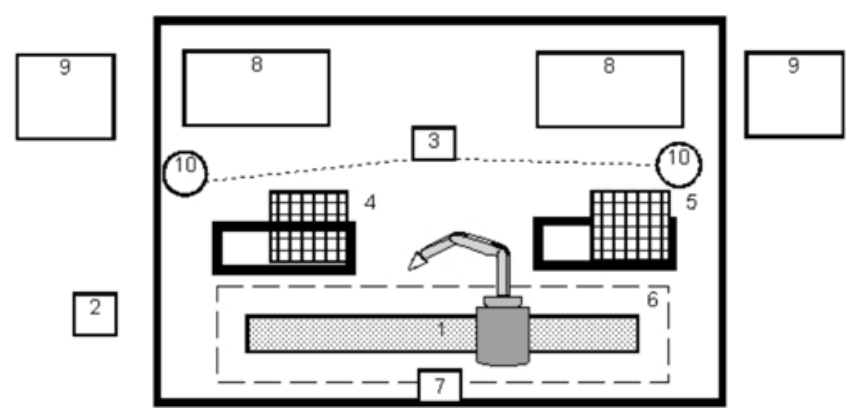

Rys. 3. Schemat stanowiska z robotem URP-6 na torze jezdnym Fig. 3. Layout of the cell with URP-6 robot on the track

\section{Stanowisko z robotem KR16 i cięciem tlenowym}

W 2007 r. TAGOR zakupił w PIAP kolejne zrobotyzowane stanowisko ukosowania z cięciem tlenowym. Tym razem zastosowano robot stacjonarny KR16 firmy KUKA (A1). Obrotowe stoły pozycjonujące (A4), (A5), rozmieszczone po obu stronach robota, mają ruszty robocze o wymiarach $900 \times 900 \mathrm{~mm}$. Stanowisko jest więc wykorzystywane głównie do ukosowania elementów małych, a także do dopalania dodatkowych wcięć i otworów w detalach i podzespołach.

Strefa pracy robota jest podzielona na dwie części: lewą i prawą. Kurtyny świetlne (A6)-(A7) oraz (A8)(A9) bronią dostępu do tych stref. Robot wyposażony jest w czujniki kontroli położenia pierwszej osi, w celu stwierdzenia, którą strefę aktualnie obsługuje. Strefa obsługiwana przez robota jest zamknięta dla operatora stanowiska. Do strefy otwartej można wejść i za pomocą żurawika (A12) rozładować/załadować znajdujący się w niej stół. Stanowisko wyposażone jest także wautomatycznązapalarkę (A13), pulpitsterowniczy (A3) i sygnalizatory świetlne (A10), (A11). Szafa sterownicza robota (A2) umieszczona jest w chronionym obszarze.

Na początku 2009 r., na miejsce wycofanego z eksploatacji stanowiska $z$ robotem przejezdnym, TAGOR zamówił w PIAP kolejne zrobotyzowane stanowisko ukosowania blach z cięciem tlenowym. Zastosowano w nim robota KR16F firmy KUKA. Stanowisko od strony obsługi jest bliźniacze ze stanowiskiem z robotem KR16. Zastosowany model robota został wyposażony w nadgarstek przeznaczony do pracy w podwyższonej temperaturze (charakteryzuje go specjalne wykonanie uszczelnień i chłodzenie przez nadmuch sprężonym powietrzem). Na stanowisku tym zastosowano stacjonarne stoły pozycjonujące bez możliwości obrotu, ale o większej powierzchni roboczej: $1500 \times 1000 \mathrm{~mm}$ (rys. 4). Pozwala to ukosować elementy o większych gabarytach niż poprzednio.

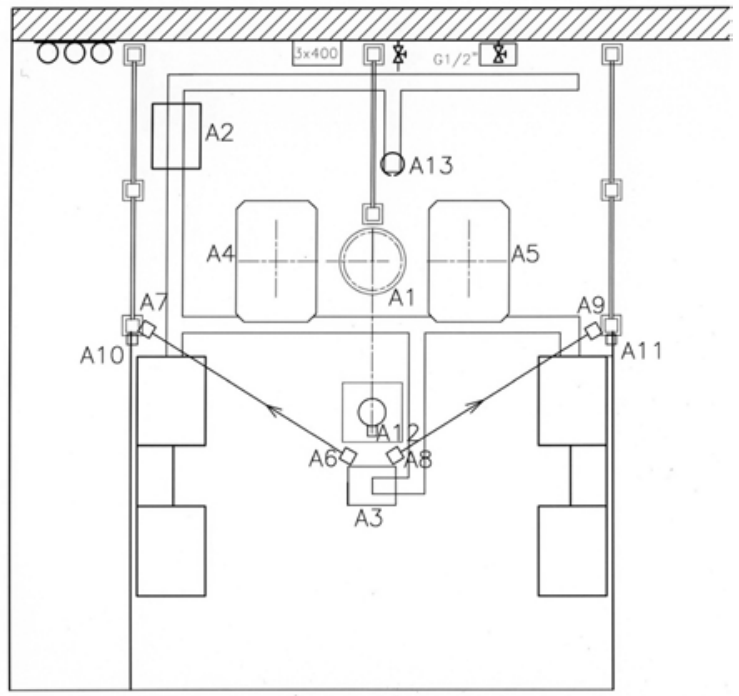

Rys. 4. Schemat stanowiska ze stacjonarnym robotem KR16 Fig. 4. Layout of the cell with KR16 stationary robot 


\section{Stanowisko z robotem KR60L30HA i cięciem plazmowym [8]}

Szczególnie efektywne jest zrobotyzowane ukosowanie przy wykorzystaniu technologii cięcia plazmowego, która pozwala uzyskać większą prędkość i mniejszą szczelinę cięcia. Dodatkowo w tym procesie węższa jest strefa wydzielania ciepła (SWC) oraz mniejsze deformacje materiału niż przy zastosowaniu cięcia tlenowego. Podczas cięcia plazmowego występuje jednak dużo wyższy poziom hałasu, a także niebezpieczne dla człowieka promieniowanie świetlne. Dlatego stanowiska wykorzystujące tę technologię muszą być wyposażone w odpowiednie zabezpieczenia i instalacje ochronne.

W 2008 r. PIAP rozpoczął w TAGOR S.A. instalację stanowiska do ukosowania dużych detali w technologii cięcia plazmowego, którego schemat przedstawiono na rysunku 5. Centralnym urządzeniem stanowiska jest robot przemysłowy KR60L30HA (A1) firmy KUKA. Robot został posadowiony na postumencie pomiędzy dwoma stołami roboczymi (A5) i (A6), o wymiarach powierzchni roboczych $1600 \times 3200 \mathrm{~mm}$, na których może być wykonywane cięcie. W związku z tym obszar pracy robota został podzielony na dwa sektory pracy - sektor lewy (L) i prawy (R). Oba stoły są wentylowane od dołu. Rury systemu wentylacji w obszarze stanowiska są poprowadzone kanałami w posadzce, podobnie jak kable zasilające i sterujące, łączące elementy stanowiska.

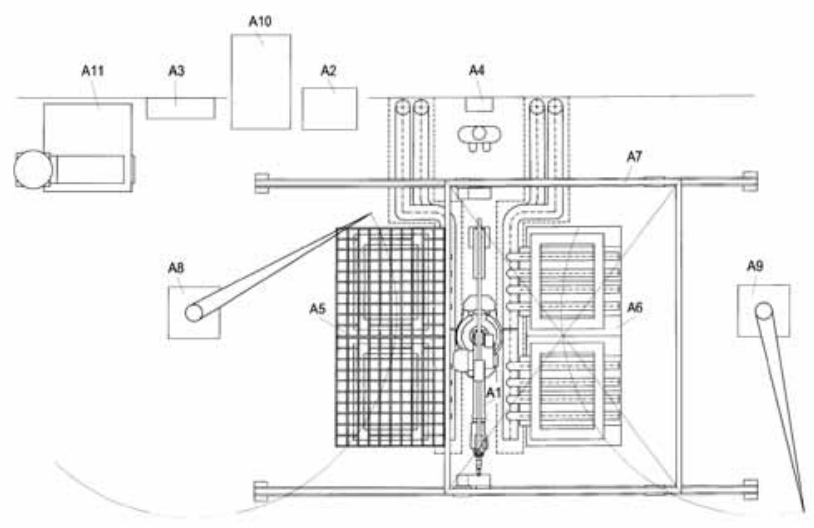

Rys. 5. Schemat stanowiska z robotem KR60L30HA i cięciem plazmowym

Fig. 5. Layout of the cell with KR60L30HA robot and plasma cutting

Narzędziem tnącym jest palnik plazmowy zasilany i sterowany przez szafę zestawu Kjellberg FineFocus800 [2]. Umożliwia on cięcie materiałów do grubości $80 \mathrm{~mm}$. Prędkość cięcia zależna jest od rodzaju materiału i jego grubości. Przykładowo, według danych producenta, dla stali niskostopowej o grubości $6 \mathrm{~mm}$ można uzyskać prędkość cięcia $7500 \mathrm{~mm} / \mathrm{min}$, dla grubości $40 \mathrm{~mm}$ odpowiednio $1100 \mathrm{~mm} / \mathrm{min}$, a dla grubości $80 \mathrm{~mm}-100 \mathrm{~mm} / \mathrm{min}$.
Wzdłuż stanowiska zamontowane jest torowisko, po którym porusza się kabina ochronna (czopuch A7). Ściany boczne kabiny są wykonane z pełnego materiału, zapewniającego wygłuszenie hałasu, który powstaje podczas cięcia plazmowego. W obu ścianach bocznych zainstalowano okna zasłonięte lamelami spawalniczy$\mathrm{mi}$, wykonanymi z materiału pochłaniającego promieniowanie świetlne pochodzące od łuku plazmowego. Obie frontowe ściany kabiny są zamykane drzwiami wypełnionymi lamelami spawalniczymi. Długość lamel jest tak dobrana, że umożliwia swobodne zamykanie i otwieranie drzwi kabiny ponad stołami. Po zamknięciu drzwi są one blokowane ryglem. Specjalny czujnik zamontowany obok rygla informuje układ sterowania, czy drzwi są dobrze zamknięte. Robot nie zacznie pracy automatycznej, jeżeli drzwi z obu stron czopucha nie są zamknięte. Podobnie, jeżeli podczas pracy automatycznej drzwi zostaną otwarte, robot przerwie pracę i wyłączy zestaw plazmowy. Kabina ochronna osłania zawsze robot i jeden ze stołów roboczych, podczas gdy drugi stół jest odsłonięty i można na nim przygotowywać detal do obróbki, używając do tego żurawików (A8) lub (A9).

Prace stanowiska nadzoruje układ sterowania zainstalowany w oddzielnej szafie (A3), ustawionej obok szafy zestawu FineFocus800 (A10) i szafy robota (A2).

W skład układu sterowania wchodzą m.in.:

- sterownik PLC zarządzający pracą stanowiska,

- sterownik bezpieczeństwa nadzorujący elementy bezpieczeństwa całego stanowiska,

- dwa sterowniki napędów przesuwu kabiny.

Obok szaf sterowniczych znajduje się agregat wentylacyjny (A11). Ma on własne sterowanie i jest osobno włączany. Agregat oczyszcza powietrze zasysane:

- od dołu spod rusztów stołów roboczych,

- od góry przez otwór w dachu kabiny.

Odciągi w stołach są podzielone na cztery sekcje - po dwie w każdym stole. Sekcje są włączane przez przepustnice sterowane sygnałami z robota. Stoły są wentylowane tylko $\mathrm{w}$ czasie cięcia plazmą. $\mathrm{W}$ danym momencie otwarta jest tylko ta sekcja, nad którą robot wykonuje cięcie.

Dużo uwagi podczas projektowania stanowiska poświęcono sprawom bezpieczeństwa. Sterownikiem bezpieczeństwa nadzorującym pracę wszystkich elementów bezpieczeństwa zainstalowanych na stanowisku jest programowalny sterownik PILZ typu m1p. Ochronę człowieka przed jadącą po szynach kabiną stanowią cztery zderzaki zamontowane na każdym rogu kabiny, które zatrzymują jej ruch po uderzeniu $w$ przeszkodę. Przestrzeń między stołami a ścianą kabiny wyłożona jest matami naciskowymi, które wykrywają wejście w ten obszar człowieka w czasie pracy robota. Drzwi do kabiny zabezpieczone są przed otwarciem za pomocą rygli i czujników. Przewidziano także ochronę przed wzajemną kolizją kabiny i żurawików, przez zainstalowanie odpowiednich czujników na słupach żurawików, informujących o kierunku wychylenia ich ramion. 


\section{Efektywność ekonomiczna} zrobotyzowanego ukosowania blach

\section{Analiza porównawcza stanowisk}

Obecnie w TAGOR fazowanie krawędzi elementów jest wykonywane na stanowiskach zrobotyzowanych oraz półautomatycznych. Do analizy porównawczej przyjęto trzy stanowiska:

1. Robot KUKA KR60L30HA i palnik plazmowy;

2. Robot KUKA KR16 i palnik gazowy;

3. Przecinarka półautomatyczna (sekator) QUICKY E.

Ze względu na różną konfigurację każdego z tych stanowisk, jako parametry do porównania przyjęto prędkość cięcia Vc $(\mathrm{mm} / \mathrm{min})$, która jest głównym parametrem decydującym o wydajności i czas wykonania (tw) $1 \mathrm{mb}$ fazy. W tablicach II $\div$ IV zestawiono te parametry.

Tablica II. Stanowisko 1

Table II. Station 1

\begin{tabular}{|c|c|c|c|}
\hline L.p. & $\begin{array}{c}\text { Wielkość fazy } \\
\mathrm{mm}\end{array}$ & $\begin{array}{c}\mathrm{Vc} \\
\mathrm{mm} / \mathrm{min}\end{array}$ & $\begin{array}{c}\mathrm{tw} \\
\mathrm{min} / \mathrm{m}\end{array}$ \\
\hline 1 & $5 \times 45^{\circ}$ & 2100 & 0.48 \\
\hline 2 & $10 \times 45^{\circ}$ & 1680 & 0,60 \\
\hline 3 & $15 \times 45^{\circ}$ & 1080 & 0.93 \\
\hline 4 & $20 \times 45^{\circ}$ & 720 & 1,39 \\
\hline 5 & $25 \times 45^{\circ}$ & 600 & 1,67 \\
\hline
\end{tabular}

Prędkość cięcia na podstawie pomiarów własnych podczas normalnej eksploatacji produkcyjnej

Tablica III. Stanowiska 2 i 3

Table III. Station 2 and 3

\begin{tabular}{|c|c|c|c|}
\hline L.p. & $\begin{array}{c}\text { Wielkość fazy } \\
\mathrm{mm}\end{array}$ & $\begin{array}{c}\mathrm{Vc} \\
\mathrm{mm} / \mathrm{min}\end{array}$ & $\begin{array}{c}\mathrm{tw} \\
\mathrm{min} / \mathrm{m}\end{array}$ \\
\hline 1 & $5 \times 45^{\circ}$ & 640 & 1,56 \\
\hline 2 & $10 \times 45^{\circ}$ & 520 & 1,92 \\
\hline 3 & $15 \times 45^{\circ}$ & 450 & 2,22 \\
\hline 4 & $20 \times 45^{\circ}$ & 380 & 2,63 \\
\hline 5 & $25 \times 45^{\circ}$ & 360 & 2,78 \\
\hline
\end{tabular}

Palniki acetylenowe Messer Griesheim, prędkość cięcia na podstawie katalogu firmy M-G. Rzeczywiste prędkości na robocie i na sekatorze są mniejsze, dobierane każdorazowo przez operatora.

Tablica IV. Czas wykonywania fazy

Table IV. Beveling time

\begin{tabular}{|c|c|c|c|c|}
\hline \multirow{2}{*}{ L.p. } & \multirow{2}{*}{$\begin{array}{c}\text { Wielkość } \\
\text { fazy, mm }\end{array}$} & \multicolumn{3}{|c|}{ Normatywny czas, $\mathrm{h}$} \\
\cline { 3 - 5 } & & $\begin{array}{c}\text { stanowisko } \\
1\end{array}$ & $\begin{array}{c}\text { stanowisko } \\
2\end{array}$ & $\begin{array}{c}\text { stanowisko } \\
3\end{array}$ \\
\hline 1 & $5 \times 45^{\circ}$ & 0,10 & 0,135 & 0,24 \\
\hline 2 & $10 \times 45^{\circ}$ & 0,135 & 0,15 & 0,26 \\
\hline 3 & $15 \times 45^{\circ}$ & 0,16 & 0,16 & 0,28 \\
\hline 4 & $20 \times 45^{\circ}$ & 0,18 & 0,17 & 0,30 \\
\hline 5 & $25 \times 45^{\circ}$ & 0,20 & 0,18 & 0,32 \\
\hline
\end{tabular}

Na podstawie tych tablic można stwierdzić, że prędkość cięcia dla plazmy jest znacznie wyższa od prędkości cięcia palnikiem acetylenowym, co jest oczywiste, przy czym daje się zauważyć następującą zależność: im wymiar fazy mniejszy, tym większa różnica pomiędzy obu prędkościami. W przypadku czasu wykonania (tw) zależność jest odwrotna, dla plazmy znacznie niższy, co wynika z wzajemnej zależności tych parametrów.

W celu zobrazowania korzyści wynikających z robotyzacji stanowisk do ukosowania oraz stosowania plazmy, w tablicy IV podano przykładowe normatywy czasu fazowania dla wybranych faz.

Normatyw czasu uwzględnia specyfikę każdego stanowiska, wyposażenie w środki transportowe, obsługę i wszystkie inne aspekty mające wpływ na czas wykonania operacji fazowania. Na podstawie przedstawionych danych widać, że dla faz o małych wymiarach najkorzystniejsza jest plazma, dla faz średnich różnica między plazmą a palnikiem acetylenowym maleje, a przy większych fazach tendencja się odwraca. W każdym przypadku stanowiska zrobotyzowane są wydajniejsze niż stanowisko 3 (z fazowaniem półautomatycznym).

\section{Zalecenia doboru typu stanowiska do fazowania detali (na podstawie stanowisk w TAGOR S.A.)}

Podczas planowania produkcji i obciążenia poszczególnych stanowisk czynione sa starania, aby maksymalnie wykorzystać park maszynowy, zapewniając oczekiwaną wydajność, przy najmniejszych kosztach. W celu wybrania stanowiska, na którym będzie wykonywane fazowanie krawędzi, oprócz parametrów prędkościowych bierze się pod uwagę i inne cechy fazowanego detalu. Zebrane są one w tablicy $\mathrm{V}$.

Tablica V. Cechy fazowanego elementu

Table V. Characteristic parameters of beveled detail

\begin{tabular}{|l|c|c|c|}
\hline \multirow{2}{*}{$\begin{array}{c}\text { Cechy fazowanego } \\
\text { detalu }\end{array}$} & \multicolumn{3}{c|}{ Stanowisko } \\
\cline { 2 - 4 } & 1 & 2 & 3 \\
\hline Długość, $\mathrm{m}$ & $0,5 \div 4$ & $\max 1,5$ & $\max 10$ \\
\hline $\begin{array}{l}\text { Maksymalna } \\
\text { szerokość, } \mathrm{m}\end{array}$ & 3 & 1,5 & 2,5 \\
\hline Maksymalna masa, T & 3 & 1,5 & 3 \\
\hline $\begin{array}{l}\text { Zakres kątów } \\
\text { ukosowania }\end{array}$ & $0 \div 45^{\circ}$ & $0 \div 60^{\circ}$ & $0 \div 60^{\circ}$ \\
\hline Wielkość fazy, mm & $0 \div 40$ & $0 \div 100$ & $0 \div 100$ \\
\hline Możliwy kształt & złożony & złożony & $\begin{array}{c}\text { prosto- } \\
\text { liniowy }\end{array}$ \\
\hline $\begin{array}{l}\text { Fazy po obu stronach } \\
\text { detalu }\end{array}$ & tak & tak & tak \\
\hline Rodzaj produkcji & seryjna & seryjna & $\begin{array}{c}\text { jednost- } \\
\text { kowa }\end{array}$ \\
\hline
\end{tabular}




\section{Podsumowanie}

Pomimo niewątpliwych zalet zrobotyzowanego ukosowania blach, technologia ta wciąż nie jest w Polsce rozpowszechniona. Głównym powodem tego stanu wydają się być koszty wdrożenia instalacji zrobotyzowanej. Składają się na nie wydatki na przygotowanie hali (adaptacja budowlana, przyłącza mediów, wentylacja, transport międzyoperacyjny) oraz na zakup urządzeń, ich zestawienie, oprogramowanie. Cena urządzeń zależy głównie od typu stanowiska i wybranej technologii cięcia. Koszt robota klasy KUKA KR16 wynosi dzisiaj ok. 30 tys. euro, czyli ok. 120 tys. zł Proste stoły robocze to wydatek rzędu kilku tys. zł. za sztukę. Sama instalacja cięcia tlenowego (przewody, zawory sterowane, palnik gazowy, akcesoria) to kolejne kilka tysięcy. Stosunkowo drogie jest spełnienie wymagań bezpieczeństwa pracy, obowiązujących od czasu wejścia Polski do Unii Europejskiej. Dla stanowiska z robotem KR16 i cięciem tlenowym trzeba się liczyć z kosztami rzędu kilkunastu, a nawet ponad dwudziestu tysięcy zł (ogrodzenie, kurtyny, sygnalizacja). W sumie same urządzenia do takiego stanowiska mogą kosztować prawie 200 tys. zł. W przypadku wykorzystania technologii cięcia plazmowego koszty są znacznie wyższe. W zamian uzyskuje się konkretne korzyści w zakresie jakości, wydajności i warunków pracy. Każdorazowo, przymierzając się do inwestycji w robotyzację ukosowania, firma musi dobrze rozważyć wymiar niezbędnych do poniesienia wydatków i wartość spodziewanych korzyści. Trudno jest podać generalną regułę przygotowania takich szacunków. Na pewno im większe spodziewane obłożenie stanowiska zrobotyzowanego, tym okres zwrotu poniesionych nakładów będzie krótszy. W pozostałych czynnikach, decydujących o opłacalności inwestycji, każdy przypadek jest specyficzny i musi być analizowany osobno, uwzględniając wszelkie aspekty techniczne, a także typ zakładu, charakter produkcji, poziom posiadanej kadry itp.

\section{Literatura}

[1] Poltowicz K.: Technologie cięcia termicznego i hydroabrazywnego, Projektowanie i Konstrukcje Inżynierskie, 10/2010.

[2] Urządzenie do cięcia plazmą FineFocus800, Instrukcja obsługi, Kjellberg Finsterwalde http://www.kjellberg.de.

[3] Hypertherm, urządzenia do cięcia plazmowego http://www.hypertherm.com.

[4] Messer - urządzenia do cięcia gazowego, http://www.messer-cw.de

[5] Pilat Z.: Robotyzacja cięcia i ukosowania blach - 15 lat doświadczeń. Przegląd Spawalnictwa 6/2010.
[6] Pilat Z.: Different Solution of Robotic Cells for Metal Sheets Beveling. Applied Mechanics and Materials Vol. 282 (2013) s. 66 $\div 73$, ( (2013) Trans Tech Publications, Switzerland.

[7] World Robotics 2011 Industrial Robots, International Federation for Robotics (IFR), VDMA, Frankfurt Germany, 2010.

[8] Hylla R. Pilat Z.: Zrobotyzowane stanowisko ukosowania blach metodą cięcia plazmowego. Pomiary, Automatyka, Robotyka nr 10/2010, s. $22 \div 27$.

\section{PLANY SPAWANIA - TEORIA I PRAKTYKA - JACEK SŁANIA}

\section{Cena}

Cena 1 egzemplarza książki Jacka Słani: Plany spawania - teoria i praktyka wynosi: 80 zł (w tym 5\% VAT)

W celu zamówienia książki w Redakcji należy wypełnić formularz zamieszczony obok i przesłać go w formie faksu, skanu lub listu na adres:

\section{REDAKCJA - Przegląd Spawalnictwa AW SIMP}

ul. Świętokrzyska 14a, 00-050 Warszawa tel.: 2282725 42, faks: 223361479 e-mail: pspaw@ps.pl

Wpłaty należy dokonać na rachunek bankowy: Bank BPH S.A. Oddział w Warszawie 45106000760000320000431836
Zamawiam książkę Plany spawania - teoria i praktyka w Redakcji Przegląd Spawalnictwa w liczbie .... egz.

Imię i nazwisko

Firma

Adres

NIP

Kontakt do osoby zamawiającej:

Oświadczam, że jestem podatnikiem VAT i upoważniam firmę do wystawienia faktury bez podpisu 